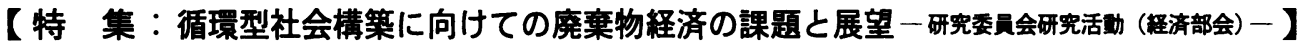

\author{
廃棄物処理とリサイクルの責任の所在
}

押谷 - *

【要 旨】廃裹物処理をめぐる法制度の目的が公䍃衛生の向上，生活環境の清潔保持といったことから， より広い環境問題や資源の保全の視点において対応することへと変化している

資源多消費型の生産・消費構造のもとで廃裹物は大量に排出され，さらに消費者二ーズの多様化に よって，有害な化学物質が含まれるため廃棄物処理は多くの問題を抱えている。

使い捨て型の生産・消費構造から資源循環型のそれへと転換することが「持続可能な経済活動」の鍵 となっており,リサイクルの推進のために法制度が整備されつつある。

しかし，一般廃棄物と産業廃棄物に区分され，それぞれ処理責任が体系的に示されているが，実際に は多くの廃裹物は, 自治体の処理体系に依存しているために, リサイクルを行うための責任所在が不明 確である。特に安価な輸入資源に依存しているために，事業者，とくにリサイクル資源を利用する製造 者にとって，リサイクルの促進や廃棄物処理費用負担などの経済的なインセンティブが働きにくい。

そこで, 今後のリサイクル法制度の課題は，すべての廃棄物は資源あるいはエネルギーとしての利用 が可能であるあのが含まれているとの認識を持ち, 廃裹物の定義の見直しやリサイクルのためのコスト 負担のあり方を検討することにあるように思われる。

「資源循環型社会」を構筑するためには，ライフスタイルの見直しを含めて，さらに事業者の役割が 強調されることが求められる。

キーワード : 事業者の役割, 責任, ライフスタイル, リサイクル

\section{1.はじめに}

最終処分場における污染防止用遮水シート破損や悪質 な廃棄物処理業者のずさんな管理によって周辺環境が污 染されていることなどにより, 最終処分場の安全性の確 保に対する住民の不安が表面化してきている。

最終処分場の建設に対する周辺住民の合意が得られな ければ, その確保は難しく, 廃棄物処理を取り巻く状況 はきわめて深刻な状況になりつつある。このままでは不 法投裹など不適正な処理処分が各地でみられるようにな り，国民経済に対して重大な影響を与えるおそれがでて きた。

今後の廃棄物政策の最も重要な論点は, 廃棄物の処理 責任はだれにあり, その責任を遵守させるための仕組み

原稿受付 1996.11.11

* 立正大学短期大学部

連絡先 : $\mathbf{7} 360-01$ 埼玉県熊谷市万吉 1700
はどのようにあるべきなのか，といったことである。

本稿では，今日の廃棄物はどのような問題を引き起こ しているのかを客観的に整理し，その解決策について処 理責任の所在の検討を中心として整理することとした。

\section{2. 今日の廃棄物問題の特徵}

物質的な豊かさは製品の購入量の增加によってもたら されるあのと考えられるが, 廃棄物は天然資源を原料と した製品がその利用価値を失ったものであり，廃棄物の 排出量は, 豊かさのバロメー夕（指標）として生活の程 度を表わすあのである1)。

ところが, 人間の産み出した廃棄物は, 排出量が大量 であること，自然環境のなかでは容易に分解されること のない化学物質が含まれていることなどから，そのまま では自然環境における物質循環あるいは自浄作用の仕組 みにのることは期待できない。そのために廃棄物処理は, 人間自らが産み出したものを, 自然の循環システムにか 
わって人工的に環境に対する影響を最小化することを基 本的な目的としていかねばならない。

廃裹物問題は経済活動に密接に関連した環境問題のひ とつであり，「持続可能な経済活動」を考える上で優先 的に解決されねばならない問題のひとつである。

かつて廃棄物が「污物」と呼ばれていた明治時代の半 ばには，衛生的視点からの措置，すなわちぺスト，腸于 フス等疫病流行の防除あるいは工業化の進展に伴う都市 廃㮖物による生活環境の悪化を背景に，ゴミ，污水，し 尿などの污物の掃除, 清潔保持, 污物処分の義務を, 土 地の所有者, 使用者などが負うことが基本的な考えと なっていた。その後，1954（昭和 29）年に「清掃法」 が制定され，廃裹物処理事業の抜本的な見直しが行われ たが，なお基本的には污物の衛生的な処理，生活環境の 清潔保持による公衆衛生の向上を図ることが基本的な考 えとなっていた。

ところが，急激な工業化にともなう高度経済成長に よって廃棄物の量的な増大，あるいは著しい質的な変化 をあたらし，1970（昭和 45）年に「廃棄物の処理及び 清掃に関する法律」(以下,「廃棄物処理法」といった場 合にはこの法律を示す）が制定され，次の二点について 処理体系が見直された。その第一は，廃棄物の定義が拡 大され, その種類は污泥, 廃油などの産業廃棄物と, そ れ以外の一般廃棄物に区分された。第二は産業廃棄物の 処理は事業者の責任とされ，一般廃裹物の処理は原則と して市町村の責任とされたことである。

廃棄物処理法の制定後も廃棄物の排出量は增加を続け, 新たな処理・処分施設の建設が連続的に求められている ために適正処理のためのコストが増大している。

地球的規模の環境問題に関するキーワードとして「持 続可能な経済活動」が提示されているように，有限な資 源・エネルギーの保全が強く求められている。

通商産業省の試算によれば, 日本の経済活動に対して 石油，石炭などの輸入資源，セメント用骨材，砂利など の国内資源および再生資源をあわせておよそ 1,839 百万 ton の資源が投入されている。このうちエネルギー消費 によって $18.9 \%$ が排ガスとして大気中に放出され大気 污染を引き起こし，炭酸ガスによって温室効果があたら されている。

このうち，ここではエネルギーの消費に伴う大気污染 の問題は除外しておく。

資源消費の視点からみると，投入された資源により農 業生産物，工業製品など 1,116 百万 ton（資源投入量の $58.7 \%$ に相当）が生産される一方で， 364 百万 ton（同 じく 19.2\%）すの産業廃裹物が排出されている。

さらに消費段階では，ストックされる 1,111 百万 ton
を除いて 125 百万 ton（同じく6.6\%）が消費され，廃 裹物として 83 百万 ton（同じく 4.4\%）排出されている。

こうした数字をみると，資源多消費・大量廃棄型と いった現代社会の構図が明らかにみえてくる。

廃裹物処理の観点からみればストックされたものもや がては廃锞物として排出されることになるので，これま での適正処理という考えから省資源・省エネルギーある いは資源の再利用を軸とした資源偱環型社会への転換が 求められており，いわゆるリサイクルの推進が注目され るようになってきた。

リサイクルを推進するために廃棄物処理法は，これま で原則として地方自治体の責任であるとされてきた一般 廃裹物の処理に対して消費者も「(前略) 排出を抑制し ……再生利用を図り……廃棄物の減量その他その適正な 処理に関し国および地方公共団体の施策に協力しなけれ ばならない（後略）」という責務があることが示された ほか，事業者に対してはリサイクル活動の推進を求める ために「再生資源の利用の促進に関する法律」が制定さ れるなど資源循環型社会をめざして具体的な役割を，事 業者, 消費者に賦課した法体系の整備が進められている。

こうした施策によっていくつかの資源, たとえば紙, アルミなどのリサイクル率の向上などがみられるものの 廃裹物の総排出を減らす効果をあげるまでには至ってい ない。

しかし，処理・処分能力は限界に近づき逼迫した状況 にあることなどから，一般廃棄物のなかに占める割合の 高い容器包装材のリサイクルをすすめることによって廃 裹物の排出量を削減するため, 通商産業省産業構造審議 会からの意見具申が行われ，これを踏まえて市町村の分 別収集と事業者による分別基準適合物の再商品化を柱と した「容器包装に係る分別収集および再商品化の促進に 関する法律（容器包装リサイクル法）」が制定された。

ところで生産と消費からはそれぞれ多様な廃棄物が排 出されているが, 日本では廃棄物を産業廃裹物と一般廃 棄物に区分し，処理体系も異なっている。一般廃衰物は 主に生活系の廃裹物であり，これに対して特定の性質を あち特定の処理技術が求められるものは産業廃棄物に区 分されている。

生産活動と消費活動はそれぞれ個別の主体であり，そ れぞれの主体の間は経済的な契約，すなわち貨幣によっ て結びついている。貨幣はすべての商品に対して交換の 可能性をむち, 現代の経済活動はその存在なしには成立 しない。従来, 生産者は商品を生産し, 消費者はそれを 消費するといった役割分担が明確であり，その意味で平 等の価値観のあとで対等な関係であると考えられた。し たがって，生産に伴う産業廃裹物はそれを排出する事業 


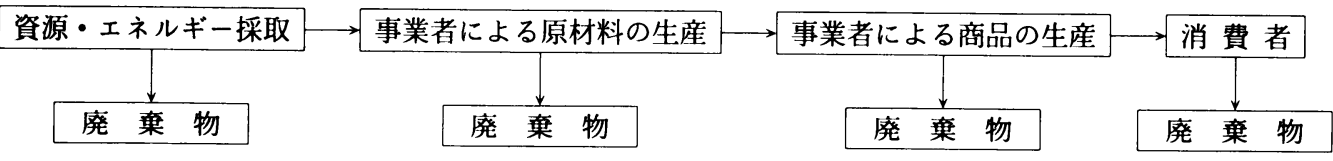

図 1 商品之廃萧物の流れ

者が，また消費によって価値を喪失した商品である一般 廃衰物の処理については消費者が責任を持つことは当然 のように考えられてきた。

しかし，これはあくまで次のような商品あるいは廃棄 物の一方通行の流れのなかで污染原因となる廃棄物の排 出者が明確な場合にのみ通用するあのである。

それぞれの主体は，その主体ごとの過程（プロセス） から発生する廃棄物だけの処理責任を持つこととし，そ のために必要となる処理費用を負担すればよい。

あちろん, 廃棄物の排出者がどの程度まで，あるいは どのような方法で廃率物を処理することが合理的である のかといったことについての評価をすることは難しく， また, 廃棄物処理の最適な水準の設定を排出側に委ねる と過小評価されるおそれがあることから，全体を見渡し てそれぞれのプロセスにとって受容可能な処理方法ある いは環境基準を設定することなどについて政策が関与し なければならないであろう。

それぞれのプロセスはこうした政策にもとづいて処理 方法・基準を遵守するために必要な投資を行い，それに よって生じるコストを負担することによって非出者は污 染に対する費用を適正に負担していくことになる。

人間が設定した基準が環境に対して最適な水準と一致 することはありえず，最適水準を達成するために必要と なる費用負担の基準，あるいはその達成状況を評価する ことは困難であるといった議論もあろうが，少なくとあ 現時点での最適な技術 ${ }^{2}$ を導入することが必要である。

そのための費用負担について，原因者が費用を負担す ることは合理的な政策であると考えられ，それに対する 解釈が OECDによって示されている3゙。

ところが、こうした污染者による費用負担の原則はあ くまで前述したように, 産業廃裹物と一般廃裹物のよう に明確に区分され排出者が特定されている場合には適用 が可能であると考えられるが，現在の廃棄物処理におい ては，それぞれの領域が不明確になっているために次に 述べるような問題点がある。

\section{1 庰棄物処理法上の区分における問題点}

産業廃裹物之一般廃裹物の区分は, 昭和 45 年に制定 された廃裹物処理法によって示された。しかしながら産 業廃裹物といっても，事業活動に伴って排出される廃棄 物をすべて示すものではなく，発生源によって産業廃棄
物に区分されるむのと「事業系」の一般廃栽物に区分さ れているあのがある。

廃裹物の区分はあくまで一般廃棄物が中心となってお り，市町村が処理することが難しいとされるものを産業 廃裹物としているだけで, 事業活動に伴って排出される 大部分の廃棄物の処理は市町村の責任とされている。

このため前述したようにそれぞれのプロセスが自分の 排出した廃棄物を処理する責任を賦課している原則とは 必ずしあなっていない。

産業廃裹物として指定されているすのは特定事業から 排出される特定の種類のあのだけに限定されているため に，大部分の廃棄物は市町村の処理に委ねられている。 さらに産業廃裹物を市町村が処理することに対しても, いわゆる「併せ産廃」として廃棄物処理法で認められて いること，広域的に処理することが適当であるとした場 合には都道府県が処理することができるなど，廃棄物処 理は自治体が行うことは法律上, 何ら問題がないことに なる。また, 産業廃棄物の処理に対しては廃裹物処理業 者への処理の委託を認めているなどから, 必ずしも事業 者は廃棄物処理を自ら完結することを求められていない。

廃裹物処理に対する事業者の責任は, 排出者の処理責 任を原則としながらも，それを補完する廃率物処理業者 や自治体（都道府県，市町村）の役割を認めているため に，事業者が自ら排出している廃棄物に対する処理責任 を全面的に認識できない構図となっている。

\section{2 廃棄物の性質の上からの問題点}

廃棄物処理法が産業廃棄物と一般廃棄物に区分されて いる基本的な理由の一つは，廃棄物の質が大きく变化し てきたことがあったとされている。処理に伴って污染物 質が排出されるおそれがあるすのや処理コストが大きい と考えられるものが産業廃裹物に区分されているが，家 庭から排出される廃棄物のなかにも処理の難しいものや, 処理コストの大きなあのあ含まれている。

たとえば，プラスチック，化学製品など石油を原料と して人工的に生み出されたものは一般的にそのままでは 自然が分解できない，あるいは分解されるまでに長時間 を要するおそれがあり，既存の焼却や埋め立てでは処理 しきれないが，日常生活ではふつうに使用されている。 さらにいわゆる「適正処理困難物」といったような概念 のものも廃棄物として排出されている。 
ここで改めて，1988（昭和 63）年に厚生省が発表し た「事業者による製品物の廃裹物処理困難性自己評価に 関する技術マニュアル・解説」による適正処理が困難な 廃裹物という概念をみてみよう。

(1) 除去, 無害化の困難な有害物質, 環境污染物質ま たはその原因物質を含有しているなどの主として化 学的, 生物学的な性状

（2) 総重量が極めて重い，容積，体積が極めて大きい， 圧縮，破砕が極めて困難であることなどの主として 物理的な性状

(3) 爆発性を有する等の処理施設を損傷する，または 作業従事者の安全衛生をそこなうおそれを有するす の

こうした適正処理困難物が市町村の廃率物処理体系の なかに多くなってきたことは, 廃棄物処理法の第 3 条第 2 項に示されている「事業者は, その事業活動に伴うて 生じた廃棄物の再生利用等を行うことによりその減量に 努めるとともに，物の製造，加工，販売等に際して，そ の製造, 加工, 販売等に係る製品, 容器等が廃棄物に なった場合においてその適正な処理が困難になることの ないようにしなければならない」という事業者の責務が 必ずしも適切に行われたとはいい難いためである。

適正処理困難物に代表されるように，現代の廃棄物に は消費者がその責任の範囲で適正に処理できないような あのも含まれるようになってきている。

一般廃衰物の処理を消費者に代わって行っている市町 村の財政的負担の增加によって廃裹物の減量化が市町村 の最大の課題である。分別排出, リサイクルなどに加え て，いわゆる「有料化」によって排出を㧕制しようとい う試みあ導入されている。

大量生産, 大量消費といった消費構造が本質的に变わ らない限り, 廃裹物の排出量が減ることはない。有料化 によって廃裹物としての排出を避けられた廃棄物は自家 処理によって処理されている4), といった報告もみられ る。自家処理は野焼きによる公害発生源の分散につなが り, 市町村による廃棄物処理に比べて環境への負荷が大 きいことが懸念される。

いずれにせよ, 現在のところ製品が廃棄物になった場 合の危険性, 環境への影響あるいは処理に際しての注意 事項といった情報は，生産者から消費者へ必ずしも十分 に提供されているとはいい難い。

1991 (平成 3 ) 年に改正された廃棄物処理法では, 爆 発性, 感染性, 有害性を有する廃棄物については他の廃 萧物に比べて公衆衛生あるいは環境保全の観点から，よ り厳しい規制をかけるために次に示すような規制を定め た特別管理廃棄物制度を導入した。
(1) 特別管理廃裹物管理責任者の設置

(2) 特別管理産業廃裹物処理業者への委託

(3) マニフェスト制度の導入

(4) 排出事業者の処理状況の報告の義務

(5) 処理業者の処理状況の報告の義務

この制度でも，依然として排出事業者による適切な管 理と監視が基本とされ，製造者の責任にまで踏み込んだ あのとはなっていない。

廃棄物処理の大部分が市町村の処理体系に委ねられて いるが生産した商品はすべてが廃棄物になるわけであり， 事業者はどこまで責任を負う必要があるのだろうか。

\section{3. 廃棄物処理に対する事業者の責任範囲}

法律上，産業廃裹物に定義されているにせよ，いない にせよ, 事業者は自分が排出している廃衰物の性質につ いては十分に把握しているはずであり，環境に対する影 響を軽減することは事業者の社会的責任で適正に行われ るべきものである。これを合理的かつ円滑にすすめてい くために国際標準機構によって ISO 14000 シリーズの環 境マネージメントシステムが示されている。設計，原材 料調達から使用, 廃棄にわたる総合的な事業者の環境管 理の必要性が示されている。ISO 14000 シリーズにおけ る廃棄物処理に対する考え方などについては別稿を期す ることとして，ここでは製造者の製品に対する責任につ いて考え方を整理してみよう。

廃秉物は製品の欠宿によるものであるということは全 くないのだが、ここでは製品はやがて廃衰物として排出 され，廃棄物は環境に何らかの影響を与えるという前提 の下で, 廃棄物（製品の最終到着地点）によって発生し た環境污染を事故と仮定してみれば，事故が発生した際 の人身あるいは財産への損害に対する責任の所在を明ら かにしなければならない。

製造物の欠陷によって人の生命, 身体あるいは財産が 被害を生じた場合における製造業者等の損害賠償の責任 については, 1994 (平成 6) 年に成立した製造物責任法 が定めている。そこで, 廃棄物の処理責任を考える上で 「製造物責任 (Product Liability；PL)」制度をかいつ まんで整理してみよう。

この制度は，製品の欠宿に伴う事故によって人身，財 産への損害が発生した場合に事後的に製造者が賠償を行 う責任制度である。従来, 民事的な責任は社会的なルー ルとして「過失責任」が適応されてきた。製造者と消費 者の間には情報が正確に伝達され, 対等な価值観のもと で商品の取り引きが行われているということが前提で あった。 
ところが，現在の多品種・小ロットによる大量生産の あとでは生産と消費が対等な契約のもとでおこなわれて おらず，過失ではなく商品の欠陥の存在を追求する「無 過失責任」という法理へ変更されてきている。これに よって事業者, 特に製造者に対して以前にも增して欠宿 製品による被害の賠償責任がもとめられてくるものと考 えられる。

1960 年代にアメリカにおいて製品の欠陥を要因とす る事故に対して, 製造者責任が認められる判決がだされ たことから「製造物責任」は国際的な関心をもたれた。 しかし，70,年代半ばに訴訟件数の增加, 評決額の高騰 や訴訟結果の不確実性が問題となった「製造物責任危 機」がアメリカにおいて発生したこと5)，ECの加盟国 の間で考え方の相違がみられることが明らかになったこ となどから議論は沈静化したが，欧州の市場統合を控え た ECにおいて製造物責任に関する指令が採択され，92 年には加盟各国で立法化されるなど製造物責任制度の導 入は国際的な流れとなっている。製品の延長線上にある 廃裹物処理においてもこうした PL 制度の考え方を十分 に検討する必要がある。

廃裹物の処理に伴って何らかの損害, すなわち冒頭で のべたような最終処分場の事故によって環境污染が生じ た場合には，污染原因となる製品の製造者が賠償しなけ ればならないはずである。

たとえば,アメリカでは有害廃衰物により污染された 土地の浄化を行うために, 総合的な環境対策, 補償およ び責任に関する法律「the Comprehensive Environmental Response, Compensation, and Liability Act of 1980 (CERCLA)」(通称，スーパーファンド 法）を 1980 年に時限立法として成立させている ${ }^{6)}$ 。化 学物質, 石油製品の製造業者などに賦課される原料税を あとに設立された信託基金によって污染地の浄化を行お うとしたあのである。その後, 1986 年にスーパーファ ンド改正再授権法「the Superfund Amendment and Reauthorization Act of 1986 (SARA)」が基金の増 額，一般企業からの環境税などの徵収などを新たに追加 して改正された。しかし，有害廃裹物によって污染され た土地は当初の予想をはるかに超えて多く, 污染修復に 要するコストあ大きいといわれている。

これらの法律は原因企業に污染修復のコスト負担を求 める点からは評価されるが, 一旦, 污染が発生した場合 には污染土虽の浄化に多大なコストを必要とすること, 責任の所在を明らかにすることの困難性があることを明 らかにしたものといえるだろう。

以上にのべてきたように, 廃棄物を産業廃裹物と一般 廃裹物に区分している現行法上では, 排出者の処理責任
が原則になっているにもかかわらず，市町村の処理に大 きく依存しており，費用負担が必ずしも合理的なもので あるのかという疑問が生じてくる。特に企業者にとって は産業廃菓物として区分されたものが限定されているこ とに加え，消費者に供給した商品が廃裹物となって廃棄 されたものまでは責任が求められていないために, 商品 の供給に何らの規制も㗢いていない。

特に産業廃裹物処理においては, 従来加それぞれの 事業者の処理責任とされてきているが，ロンドン条約》) による海洋への廃棄物投裹の原則禁止，他国への有害廃 裹物などの委託処理禁止など8), 廃率物処理はより撖密 に排出者処理責任が強化されるようになってきている。

また，廃棄物のなかの有害性あるいは危険性が人の健 康や環境に著しい影響を与えるおそれるあり，その原因 が一般廃棄物であれ産業廃棄物であれその净化には莫大 な修復コストが必要となり，結局は事業者がそれを負担 せざるを得ない昂。

さらに，製造物の欠陥によって人の生命，身体または 財産に被害が生じた場合の製造事業者の責任を問う「製 造物責任」が廃棄物処理にも求められる可能性もある。

日本では廃棄物処理に対するコスト負担イコール責任 の遵守とされている。

廃率物処理に伴うコスト負担の前提として, OECD が 72 年に示した「環境政策の国際経済面に関する指導 原理」において提唱した污染者費用負担の原則（Polluter Pays Principle; PPP) によって前述のように産 業廃㪰物は排出事業者, 一般廃棄物は市民（原則として 市町村が代行しているが）とされてきた。しかしながら， OECD のPPPは「污染者」という概念に対して, これ がだれを指すのかを明確に示していない。日本の産業廃 菓物の場合には, 事業活動に伴って排出するあのであり, これの処理に伴う費用を負担するのは合理的であり, 一 般廃棄物の場合においても，その処理を市町村が処理す るにあたって排出者が税負担を通じて, あるいは排出量 に応じて処理費用の負担を求めることは合理的であると 考えられる。

しかしながら消費者はあくまで利便性を享受するため に事業者によって生産・供給された「財」を購入し， 「財」の価値の喪失した廃棄物を排出しており，必ずし も污染物質を排出しているわけではなく，「污染可能性 のある」廃棄物を排出しているだけであるとした場合に は, 一般廃裹物の処理における PPPにおいて製造者責 任についても十分に考慮しておく必要がある。

資源・エネルギーあるいは地球環境の保全の視点から これまでの廃衰物処理体系ではなく, 循環型社会へと転 換していくことが求められ企業経営のなかで, 廃裹物処 
理を適正に評価することが強く求められる。

商品を市場に作り出してきた事業者は, それが廃裹物 になってもそれを適正に処理し，資源として循環させる 技術あるいは，適正なコストを負担するべきであり，ま た，行政はそれを誘導する面から法制度の整備をすすめ ていくことが今後の課題であろう。このまま市場経済の メカニズムを保持していく限り, 廃率物の増加が続くこ とは避けられそうにないといえるだろう。とすれば廃棄 物の排出量の規制あるいはリサイクルの促進によって減 量化を目指していかねばならない。廃棄物の排出を規制 してもなんらかのかたちで処理あるいは最終処分が必要 となる廃棄物の排出は皆無にはならないことを考えれば, 当面, リサイクルによって廃裹物の処理・最終処分を回 避することが効果的であると考えられる。

\section{4. リサイクルの効果と課題}

人類はその活動の基盤としての資源・エネルギーが自 然環境中に無限の容量をもつものと解釈し, 不要物とし ての污物，ガス，水などを環境中に排出し続けてきた。 いわば環境が無限な眝葴庫であり, 無限に廃棄物を受け 入れてくれる許容能力があると信じてきた。

特に産業革命, 第二次世界大戦の終結, 東西冷戦構造 の終結，あるいは途上国の急速な工業化など，経済活動 の大きな変化に伴って資源・エネルギーの消費量と環境 への廃棄物の排出量が増大していったが, 自然環境の持 つ自浄能力は無限ではなく, 人間の様々な活動が原因と なって多くの環境問題を産み出していったこと融あ明ら かになってきた。有限で非再生資源である鉱物資源, エ ネルギー資源は枯渴するおそれが指摘されている ${ }^{11)} 。$

一方，環境は無限の「ごみ箱」ではないことも，各地 で不法投裹による環境污染や廃棄物埋め立て地から污染 物質が漏れ出している事件が発生していることからあ明 らかになってきた。今のところ深刻な健康被害や環境污 染などは報告されていないが，環境へ污染物質を不適切 に放出した場合には深刻な問題が生じることは, 公害病 の経験からも明らかな通りである。

特に経済活動のために自然から資源を取り出し，その 資源を用いて企業などが生産活動を行い，そこから排出 される産業廃裹物, あるいは生産された生産物を手にし た家計・消費者は消費活動から一般廃棄物を排出してい る。資源の安定的な確保大および廃棄物の適正な処理に よる污染の回避は現代の経済において本質的な課題とな りつつある。

リサイクルは省資源・省エネルギー効果とともに廃棄 物処理に代替する効果を持っていることからその推進は
社会的要請であるように思われる。

廃裹物の適正な処理の観点からは廃衰物処理法が, 再 生資源の原材料としての利用の観点からはリサイクル法 が，それぞれ改正，あたらに制定され排出抑制，分別・ 再生など洎環型社会構築のための法制度が整備されてき た。

これら一連の法制度の整備は，廃棄物あるいはごみと よばれるあののなかに資源あるいはエネルギーとして利 用できる部分が含まれていることから，これをリサイク ルすることによって，資源の保全，そして廃衰物排出の 抑制を目的とするあのである。

ところが，廃棄物排出量は顕著に減少することはなく， 品目毎のリサイクルの現状をみると, 廃プラスチックな どのように経斉的にリサイクルが進まないあのなど，い くつかの問題があることなどが明らかになってきた。特 に，ごみから集められた「資源ごみ」を業者が引き取り にこなかったり, 資源あるいはエネルギーとして価値が あるにあかかわらず逆に引き取ってもらうためにカネを 払わなければならない「逆有償」といったような経済面 での困難性に直面している。

リサイクルといっても, 現代の資本主義経斉あるいは 自由競争といった経済原則に基づいていることを考えれ ば，既存のシステムでリサイクルが行われていないもの は経済性がないのである。このような経済性がないあの をいかに法制度を整備してあリサイクルは進まないとい えよう。

特に戦後 50 年で容器, 包装材は大きく変化し, 廃棄 物の排出量の増加の原因となっているといわれ，1995 年に容器包装リサイクル法が制定された。

この法律では, 事業者の引き取り義務, 容器包装の対 象範囲，第三者機関の設立など省庁間で激しい議論が展 開された。その結果,びん，缶，紙，プラスチック製の あの等, 商品に付されたすべての容器包装に対して分別 の徹底, 再商品化の促進とともに, ごみの減量化, 適正 処理の推進と再生資源の利用を図ることの制度化が行わ れた ${ }^{12)}$ 。

しかしながら，現代の廃裹物問題は，このような法制 度による責任論あるいは役割分担だけでは対応できず， さらに事業者, 特に製造業者の役割分担が強化されるべ きであるということである。

今日の廃棄物の排出量の増加問題の背景には, 現代社 会の資源・エネルギーの大量消費, 商品の大量生産にあ ることは既に述べてきた。こうした市場にあふれる商品 よって恩恵を得てきたのは消費者であったが，大量消費 によって増加している廃棄物について，その処理を消費 者あるいは自治体だけに委ねることは財政的に困難に 
なってきており，安定した経済活動に影響を与える恐れ もある。

その対応策として進められているリサイクルにおいて も，本来リサイクルが成立するだけの十分な市場がない ことなどの経済的な制約から抜本的な効果はあがってい ない。

つまり, 容器包装リサイクル法などによって排出者と 事業者それぞれに分別あるいは収集の責任を持たせ，物 質循環の流れは整備されてきたが，経済性あるいは技術 的な対応が十分とはいえないのである。こうした面につ いては，事業者自身がリサイクル資源の利用を促進して いくこと, 用途開発，品質の向上といった技術的な対応 をはじめとして，自然環境あるいは資源・エネルギーの 保全の視点から新たな経済性に対する認識をあつ,より 一層の対応が期待されている。

つぎに循環型社会構築のためにいくつかの視点から事 業者のあり方を整理してみよう。

\section{5.リサイクル推進のための責任の所在}

容器包装リサイクル法においては事業者は家庭から排 出される廃率物のうち, 容積比で $57.5 \%$, 重量比で $23.3 \%$ を占める容器包装廃裹物 ${ }^{13)}$ をサイクルすること になっており，省資源・省エネルギーあるいは廃裹物処 理量の減量化に貢献する。

廃棄物処理法では廃棄物が産業廃棄物と一般廃棄物に
区分され，その処理において産業廃裹物は排出事業者, 一般廃裹物は排出者である消費者の責任とされ，処理費 用を負担することによって排出者費用負担の原則とされ てきた。一方、リサイクル活動は市場メカニズムにもと ずく経済活動であることから，廃裹物処理法における処 理責任には該当しないこととされてきた。

ところが，市場メカニズムに委ねられたリサイクル活 動は一次資源価格，製造コストなどによって大きく左右 される。容器包装リサイクル法は一般廃棄物のなかの容 器包装材のリサイクルを進めるために，事業者に対して 市民・市町村によって分別回収された容器包装材をリサ イクルするための再商品化を求めている。このことは, 再商品化は事業者による市場を経由することになる。

事業者, 消費者, 市町村それぞれのプロセスが市場に よって何らかの利益を得られれば市場メカニズムのいわ ゆる「見えざる手」で推進されるのであろうが，再生資 源の市場は不安定であり分別回収が進むと再生資源の工 ンド・ユーザーへの供給過剩(14)になることによって值崩 れをおこすことがある。市場メカニズムだけで，回収量 の増加やリサイクル率を向上させることは非常に難しい。 さらに，事業者に対して費用負担を求めても，製品価 格への転嫁によって結局は消費者が費用負担することに なることについても考慮して置かねばならない。

たとえば，主なリサイクル可能物とそのリサイクルに 対する法体系と処理責任等については次の表に示す通り である。

表 1 リサイクル可能物とそのリサイクルに対する法体系と処理責任

\begin{tabular}{|c|c|c|c|c|c|c|c|}
\hline \multicolumn{2}{|l|}{ リサイクル } & \multicolumn{2}{|c|}{ 製 } & \multicolumn{2}{|c|}{ 消 費 者 } & \multicolumn{2}{|c|}{ 自治体（市町村） } \\
\hline 可 能 物 & *法 律 & ***責任 & 方 & 責任 & 法 & 責任 & 法 \\
\hline 紙 & $\begin{array}{l}\text { 再利用促進法 } \\
\text { 容 R 法 }\end{array}$ & $\begin{array}{l}\mathrm{O} \\
\text { 再 }\end{array}$ & $\begin{array}{l}\text { 再生資源の原材料と } \\
\text { しての利用の促進 }\end{array}$ & $\begin{array}{l}\bigcirc \\
\text { 容 }\end{array}$ & $\begin{array}{l}\text { 分別排出への } \\
\text { 協力 }\end{array}$ & $\begin{array}{l}\bigcirc \\
\text { 容 }\end{array}$ & $\begin{array}{l}\text { 分別収集計画 } \\
\text { の策定・実施 }\end{array}$ \\
\hline ガラスびん & $\begin{array}{l}\text { 再利用促進法 } \\
\text { 容 R 法 } \\
\end{array}$ & $\begin{array}{l}\bigcirc \\
\text { 再 }\end{array}$ & $\begin{array}{l}\text { 再生資源の原材料と } \\
\text { しての利用の促進 }\end{array}$ & $\begin{array}{l}\bigcirc \\
\text { 容 }\end{array}$ & $\begin{array}{l}\text { 分別排出への } \\
\text { 協力 }\end{array}$ & $\begin{array}{l}\bigcirc \\
\text { 容 }\end{array}$ & $\begin{array}{l}\text { 分別収集計画 } \\
\text { の策定・実施 }\end{array}$ \\
\hline PET ボトル & $\begin{array}{l}\text { 再利用促進法 } \\
\text { 容 R 法 } \\
\end{array}$ & $\begin{array}{l}\bigcirc \\
\text { 再 } \\
\end{array}$ & 分別のための表示 & $\begin{array}{l}\text { O } \\
\text { 容 }\end{array}$ & $\begin{array}{l}\text { 分別排出への } \\
\text { 協力 }\end{array}$ & $\begin{array}{l}\bigcirc \\
\text { 容 }\end{array}$ & $\begin{array}{l}\text { 分別収集計画 } \\
\text { の策定・実施 }\end{array}$ \\
\hline $\begin{array}{l}\text { 缶 } \quad \text { (スチー } \\
\text { ル・アルミ) }\end{array}$ & $\begin{array}{l}\text { 再利用促進法 } \\
\text { 容 R 法 } \\
\end{array}$ & $\begin{array}{l}\bigcirc \\
\text { 再 }\end{array}$ & 分別のための表示 & $\begin{array}{l}\bigcirc \\
\text { 容 }\end{array}$ & $\begin{array}{l}\text { 分別排出への } \\
\text { 協力 }\end{array}$ & $\begin{array}{l}\bigcirc \\
\text { 容 }\end{array}$ & $\begin{array}{l}\text { 分別収集計画 } \\
\text { の策定・実施 }\end{array}$ \\
\hline 自動車 & 再利用促進法 & $\begin{array}{l}\text { ○ } \\
\text { 再 }\end{array}$ & $\begin{array}{l}\text { 製品アセスメントの } \\
\text { 実施 }\end{array}$ & - & - & - & - \\
\hline 家 電 & 再利用促進法 & $\begin{array}{l}0 \\
\text { 再 }\end{array}$ & $\begin{array}{l}\text { 製品アセスメントの } \\
\text { 実施 }\end{array}$ & - & - & - & - \\
\hline スラグ & 再利用促進法 & $\begin{array}{l}\mathrm{O} \\
\text { 再 }\end{array}$ & $\begin{array}{l}\text { 発生する副産物の利 } \\
\text { 用 }\end{array}$ & - & - & - & - \\
\hline 石炭灰 & 再利用促進法 & $\begin{array}{l}0 \\
\text { 再 }\end{array}$ & $\begin{array}{l}\text { 発生する副産物の利 } \\
\text { 用 }\end{array}$ & - & - & - & - \\
\hline
\end{tabular}

* 役割が示されている法 再利用促進法；再生資源の利用の促進に関する法律 容 R 法 ; 容器包装に係る分別収集及び再商品化の促進等に関する法律

**リサイクルするために何らかの責任の所在が法律で示されている場合には「○」印をつけた 再; 再生資源の利用の促進に関する法律

容；容器包装に係る分別収集及び再商品化の促進等に関する法律 
リサイクル法と容器包装リサイクル法は家庭から排出 される一般廃裹物に含まれる容器包装材のリサイクルの 促進に対して密接な関連をもち, リサイクル法は事業者 の，容器包装リサイクル法は消費者および市町村の役割 について定めている。

事業者の役割についてリサイクル法では「再生資源の 原材料としての利用を促進する」, 容器包装リサイクル 法では「再商品化義務量の再商品化」という別の用語を 使用しており，用語の意味はわかりにくいが，何らかの 形で事業者に対してリサイクルに対する責任を求めてい るあのと理解しておくことができるだろう。

さらにビールびんのようにリターナブル容器を特定事 業者か販売店を通じて回収している場合には，容器包装 リサイクル法の再商品化義務量から控除されるためであ る。

いずれにせよ, 容器包装材のような一般廃棄物につい て，これをリサイクルするにあたっては排出者である消 費者の責任だけでは完結せず，事業者の対応が不可欠で ある。

\section{6. 㡒環型社会構策のための課題}

循環型社会とは，廃裹物、リサイクル資源の流れをス ムーズにすることであり, 事業者, 排出者, 処理事業者, 排出事業者の間で処理およびリサイクルに関する情報を 共有することが不可欠である。

そのためには関係者の間で排出量，処理方法などをは じめとする情報を共有するための高度の情報管理システ ムの管理が必要である。たとえば見在，厚生省が事業化 の準備をすすめている産業廃棄物のマニフェスト（廃棄 物処理管理伝票) の電算化システムは, 産業廃裹物の移 動管理の強化を目的としているが，将来的には上流側の 物資の物流管理と下流側の廃裹物処理およびリサイクル とを結合することによって，ごみ処理の視点からあ資源 循環型社会を稼働させるための有力なインフラストラク チャーになることが期待される。事業者は自ら製造した 商品の材質表示, リサイクルを容易にする製品設計など に積極的に取り組み，それらの情報を開示していくこと あ求められよう。

容器包装リサイクル法は, ごみの処理あるいはリサイ クルの促進にあたっても事業者の役割があることを示し たことで評価されるべきである。

しかし，廃棄物処理にあたってはこうした法制度に よって誘導するべき面と，市場の自由競争原理による面 があることを無視してはならない。

特にごみのなかに含まれる資源分のリサイクルの促進
を考えた場合には，消費者が分別し，市町村が回収し， 事業者がそれを利用することであり，リサイクル資源の 用途や利用者を十分に把握しておくことが重要であり，

リサイクル市場の経済性といった面を十分に把握してお くことが求められる。

自治体の公共政策としての廃裹物処理においては，そ の地域特性, 廃裹物の排出特性などを踏まえて, 適正な 処理技術，規模あるいは他の主体，たとえばリサイクル 資源を利用する事業者との連携やリサイクル促進のため の技術開発に関する補助金などのソフト面の対応を強化 することも必要であろう。

紙，缶などのリサイクル可能分の回収がすすむと，再 生資源の市場が極度に低迷するおそれすあり，回収を 「業」としている業者の間から対策が求められている。 回収を進めている自治体の間にもいわゆる「逆有償」で あるにもかかわらず有価物の回収を続けているところも みられる。リサイクルのための回収が一定の水準，すな わち再生資源の需給のバランスを超えてしまった場合に は，再生資源の暴落あるいは高騰を招くおそれがある。

すなわち, リサイクルは廃棄物排出量を削減する効果 は期待できるが，市場経済に委ねられた再生資源の市場 に対して影響を与えてしまい，結局は回収を進める上で 限界があるということである。

余剩の再生資源が価格の暴落を招き，それが回収に対 する負のインセンティブになっているとすれば,このま ま市場のメカニズムに委ねた回収量に抑えておくべきな のか，それとも廃裹物の減量化のために回収量を增加さ せていくべきなのであろうか。

廃率物処理が自治体の処理体系を中心としていること はすでに述へてききた。自治体は公共政策として廃棄物処 理に伴う環境問題をできるだけ回避するためにその処理 に取り組まねばならない。しかし，廃棄物処理に対する 財政負担が膨らんでいることからこれを削減すること あ政策課題の重要なポイントであるはずである。

とするならばリサイクルのために再生資源を回収し， それによって廃菓物処理量を削隇することは最も合理的 な政策として評価されなければならない。

自治体の廃裹物処理に関する公共政策がリサイクルの 促進を選択するのであれば，消費者あるいは事業者もそ れぞれの立場からリサイクルの促進に対する役割を担わ なければならない。

リサイクル法, 容器包装リサイクル法において示され ている事業者, 消費者, 国・自治体の役割を再確認する ことが当面の重要な課題である。 


\section{7.結ひにかえて}

リサイクルといっても，現代の企業および消費の行動 は, 自由競争といった経済原則にもとづいていることを 考えれば, 既存のシステムでリサイクルが行われていな いものは，その物質のリサイクルに関する経済性はない といえるのである。このように経済性がないあのをいか に法制度を整備してあリサイクルは進まないということ を考えねばならない。

容器包装リサイクル法では, 事業者の引き取り義務, 容器包装の対象範囲, 第三者機関の設立など省仃間で激 しい議論が展開された。その結果, びん, 缶, 紙, プラ スチック製のもの等, 商品に付されたすべての容器包装 に対して分別の徹底, 再商品化の促進とともに, ごみの 減量化，適正処理の推進と再生資源の利用を図ることの 制度化が行われた ${ }^{15)}$ 。

しかしながら，現代の廃裹物問題は，このような法制 度による責任論あるいは役割分担だけでは対応できず, さらに抜本的な対策が必要となっている。

たとえば，今日の廃棄物の排出量の増加問題の背景に は, 現代社会の資源・エネルギーの大量消費, 商品の大 量生産があり，資源問題との関連性をもっている。

市場にあふれる商品よって恩恵を得てきたのは消費者 であったが，大量消費によって增加している廃棄物にっ いて，その処理を消費者あるいは自治体だけに委ねるこ とは財政的に困難になってきており，安定した経済活動 に影響を与える恐れあある。

その対応策としてすすめられているリサイクルにおい ても，本来リサイクルが成立するだけの十分な市場がな いことなどの経済的な制約から抜本的な効果はあがって いない。

つまり, 容器包装リサイクル法などによって排出者と 事業者それぞれに分別あるいは収集の責任を持たせ，物 質循環の流れは整備されてきたが, 経済性あるいは技術 的な対応が十分とはいえないのである。こうした面につ いては，事業者自身がリサイクル資源の利用を促進して いくこと, 用途開発, 品質の向上といった技術的な対応 をはじめとして，自然環境あるいは資源・エネルギーの 保全の視点から新たな経済性に対する認識をもったより

一層の対応が期待されているということである。

容器包装リサイクル法は, ごみの処理あるいはリサイ クルの促進にあたっても事業者の役割があることを示し たことで評価されるべきである。

しかし，廃棄物処理にあたってはこうした法制度に よって規制するべき面と, 市場の自由競争原理によって 誘導されるべき面があることを無視してはならない。
特に廃茟物のなかに含まれる資源分のリサイクルの促 進を考えた場合には，消費者によって分別され，市町村 が回収し，事業者がそれを利用するということになるの で，リサイクル資源の用途や利用者を十分に把握してお くことが重要であり,リサイクル市場の経済性といった 面を十分に把握しておくことが求められる。

法制度の関与, あるいは廃率物処理に責任をもってい る目治体の公共政策としての廃棄物処理においては，そ の地域特性, 廃裹物の排出特性などを踏まえて, 適正な 処理技術, 規模あるいは他の主体，たとえばリサイクル 資源を利用する事業者との連携やリサイクル促進のため の技術開発に関する補助金などのソフト面の対応を強化 することも必要であろう。

廃棄物処理は，これまで一般廃棄物については消費者 の処理責任を代行するかたちでおこなわれてきたのは当 然として, 産業廃栽物に該当しない多くの「産業活動に 伴う」廃棄物も地方白治体が行ってきた。しかし量の增 大, 質の多様化などから, 自治体の処理体系だけでは対 枕できなくなってきている。

特に有害性あるいは危険性のある廃棄物が含まれるよ うになってきたことなどから，その特性を理解している 排出事業者が処理することが最もふさわしいとも考えら れる。特に産業廃裹物処理においては従来からそれぞれ の事業者の処理責任とされてきているが，ロンドン・タ ンピング条約 (London Convention) ${ }^{16)}$ による海洋へ の廃棄物投裹の原則禁止, 他国への有害廃棄物などの委 託処理禁止などを定めたバーゼル条約17)（Bazel Convention）などによって, 廃率物処理はより厳密に排出 者処理責任が強化されるようになってきている。こうし たなかで，廃裹物処理においては製造業者などが排出す る産業廃棄物と, 消費者が排出する一般廃棄物の境界を 見直すことも場合によっては求められる。

廃異物のなかの有害性あるいは危険性が人の健康や環 境に著しい影響を与えるおそれもあり，その原因が一般 廃棄物であれ産業廃棄物であれその浄化には莫大な修復 コストが必要となり, 結局は事業者がそれを負担せざる を得ない(18)が，それによって影響を受けるのは消費者で ある。

地球環境あるいは資源・エネルギーの保全の視点か らこれまでの廃棄物処理体系ではなく, 循環型社会へ と転換していくことが求められているなかで廃菓物処 理によって生じる環境影響あるいは資源の価值をLife Cycle Assessment (LCA) などの手法によって適正に 評価することが求められる。

廃棄物処理を中心に消費構造のあり方をみることが可 能ならば，その処理に好ましくないものに課税して相対 


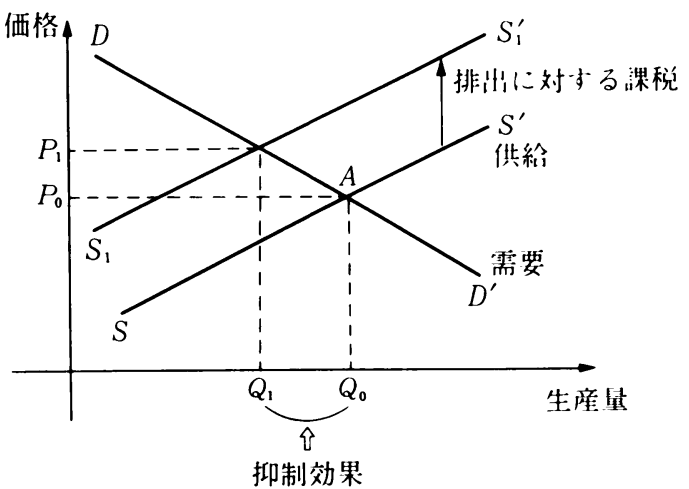

図 2 課税効果

的に価格を上げることもひとつの考え方である。

たとえば資源・エネルギーを大量に消費しながら使い 捨てられる容器や, 有害物質を含むものに対しては, 課 税することによって結果的に排出を抑制させることであ る。

単純な需要と供給の説明図を用いて説明してみよう。 当初の需要と供給の均衡は $A$ 点で示されているが, 課 税することによって，生産財の価格は高くなるために産 業全体の供給曲線は左上方にシフトする。これによって 価格は $P_{0}$ から $P_{1}$ に上昇し, 生産量および排出量は $Q_{0}$ から $Q_{1}$ へ減少する。

廃棄物排出量の抑制にあたっては，それぞれの主体に 対して責任が賦課されねばならず，消費に対する何らか の制約は止むを得ないと考えられる。こうした課税政策 の導入についてあ検討しなければならない。むろん，そ の代替案を誘導するための補助金などの政策が用意され ねばならず，その影響と効果についての総合的な検討を 踏まえた政策を検討することが必要である。

\section{考文献}

1) 田中 勝監修「リサイクル 世界の先進都市から」リサ イクル文化社, pp. 14-16 (1993)

2) 例えば, Best Available Technologyといった概念 が地球環境問題の対策を考えるトで主流になりつつあ る。

3) OCEC, The Polluter Pays Principle : Definition, Analysis, Implementation, OECD (1975)

4) 田中信寿「一般家庭における資源消費節約型生活に対 する有料化の効果に関する研究」

5 ） 国民生活審議会 消費者政策部会報告資料より，通商
産業省産業政策局消費経済課編「製造物責任法の解説」, 通商産業調查会 (1994)

6 ）植田和弘「スーパーファンドの中間決算書」, 公害研究 Vol. 19, No. 4 (1990)

7 ）「咸棄物その他の物の投裹による海洋污染防止に関する 条約」

8 ）「有害廃棄物の越境移動及びその処分の管理に関する条 約」

9 ）例えば米国のスーパーファンド法は有害廃裹物による 污染処分場の環境修復コストを確保するために事業者 に基金の拠出を求め基金（ファンド）を設けている。 法律の内容などについては，松村治夫「新しいスー パーファンド法」（1987）いんだすと, Vol.2, No. 2 などを参照されたい。

10）福岡克也「地球環境保全戦略」有斐閣選書（1993）

11）西山孝「資㟲経済学のすすめ」中公新書 (1993)

12）容器包装リサイクル法の成立の背景, 概要等について は，松村治夫「エコテクノロジー一資源循環型社会 の構築に向けて一」日本学術振興会素材プロセシング 第 69 委員会資料（1996 年）などに詳しく述べられて いる。

13）厚生省生活衛生局水道環境部環境整備課監修,「容器包 装リサイクル法のあらまし 時代に新しい風」,ぎょう せい（1995）

14）日経新聞（1996 年 9 月 28 日朝刊）によれば市町村の ごみ処理費用の削減のために古紙の囘収業者に対する 助成金を出し続けているために製紙業者が古紙回収業 者から買い上げる価格が低迷しているにあかかわらず 供給過剩が続いている。

15）容器包装リサイクル法の成立の背景, 概要等について は，松村治夫「エコテクノロジー一資源循環型社会 の構築に向けて一」日本学術振興会素材プロセシンク 第 69 委員会資料（1996 年）などに詳しく述べられて いる。

16）「廃棄物その他の物の投㙌による海洋污染防止に関する 条約」

1975 年に採択, 日本は 80 年に批准した。陸上で発 生した廃裹物の海洋投裹及び洋上.での焼却による海洋 污染を防止しようとするすの。

17）「有害廃衰物の越境移動及びその処分の管理に関する条 約」

国連環境計画を中心に 1989 年に採択された条約で有 害廃棄物の越境移動を国際的に管理することによって 廃裹物の越境移動に伴う不適正な処理による途上国の 環境污染を未然に防止することなどを目的としている。

18）例えば米国のスーパーファンド法は有害廃棄物による 污染処分場の環境修復コストを確保するために事業者 に基金の拠出を求め基金（ファンド）を設けている。 


\title{
Prospected Role of Waste Management and Recycling Activities for the Future
}

\author{
Hajime Oshitani \\ Rissho University, Junior College \\ (1700 Mankichi, Kumagaya-shi, Saitama 360-01 Japan)
}

\begin{abstract}
The object of this paper is to summarize the prospected role of waste management and recycling activities for the future. We are currently facing some difficulty in appropriately securing a final disposal site. Human activity, the production and consumption of goods is discharging huge amounts of waste which contain various hazardous materials. We therefore have to establish an artificial resource circulation system to replace natures' self-cleaning system. We also have to more efficiently conserve limited natural resources and energy to achieve "Sustainable Development."

A Resource-Circulation Society, based on wide-ranging recycling activities, must be created. Some recycling activities are not economical feasibility in Japan due to the cheaper price of raw materials or high cost of processing, etc.

Legislative formulations have recently been changed to promote recycling activities.

I would like to emphasize the role of enterprises and industries which are producing products and utilizing secondary materials from recycling. Consequently, there is no need to divide these into industrial waste and municipal waste, and wastes from industrial activities are treated and disposed of by municipalities right along with household waste.

We have to realize that all wastes can be utilized as resources or energy, and that industry must therefore share in the recycling cost. Moreover, we have to discuss the possibilities of changing our overconsuming lifestyles which are continuously discharging huge amounts of waste.
\end{abstract}

Key words : proper role in industry, liability, lifestyle, recycling 